
www.globaljournalseries.com; Info@globaljournalseries.com

\title{
RELATIONSHIP BETWEEN THE PERCEIVED EFFECTS OF THE IMPLEMENTATION OF STRATEGIC PLANNING PROCESS AND HEAD TEACHERS' PERFORMANCE IN PUBLIC DAY PRIMARY SCHOOLS IN KERICHO COUNTY OF KENYA
}

WILLIAM KIPROTICH CHEPKWONY, J. K. KIBETT, AND J. G. MANDUKU

(Received 2, October 2020; Revision Accepted 9, November 2020)

\begin{abstract}
The purpose of this study was to investigate the relationship between perceived effects of the implementation of strategic planning process and head teachers' performance in public day primary school in Kericho County of Kenya. The study used an ex-post-facto research design. The research approach used was quantitative and qualitative. The target population comprised of 524 head teachers of public primary schools in Kericho County. The research instruments used to collect the data were questionnaires and interview schedules. A sample of 227 headteachers and Six (6) Sub County Directors was obtained using Stratified Random Sampling and Purposive sampling technique respectively. Data was collected using a questionnaire that was developed by the researcher. Simple random sampling technique was used to select schools in each sub County. A pilot study was done on 23 headteachers who were not included in the final study to determine reliability of the research instruments. Cronbach alpha formula was used to determine reliability coefficient. A score of 0.7 and above was deemed acceptable. Data was analysed for descriptive statistics (frequencies and percentages) and inferential statics (Pearson correlation and Regression analysis). The results were presented in form of tables and figures. The results show that implementation of strategic planning process did not have a statistically significant relationship with head teachers' performance in primary day schools in Kericho County. There was a positive correlation between results of strategic planning process and head teachers' performance at $(r=135 ; p=0.056)$.
\end{abstract}

KEYWORDS: Strategic Planning Process, Head Teachers' Performance, Public Day Primary School, Perceived effect of implementation

\section{INTRODUCTION}

Thompson, Strickland \& Gamble (2010) defines strategic planning as a competitive step and business approach that managers use to develop businesses, attract and thrill customers, successfully compete, operate and achieve targeted performance levels. The process involves making strategic decisions to position companies ahead of their competitors over the long term (Fullan 2004; Quong \& Walker 2010). Implementation of strategic planning process is

William Kiprotich Chepkwony, University of Kabianga Box 2030-20200 Kericho

J. K. Kibett, University of Kabianga Box 2030-20200 Kericho

J. G. Manduku, University of Kabianga Box 2030-20200 Kericho 
supposed to help school managers to perform better in executing their mandate in school. The performance of school managers is critical for school effectiveness (Steyn \& Wolhuter, 2010). However, the implementation of strategic plans in many schools in Africa is still below expectations (Chukwumah \& Ezeugbor, 2015).

In Kenya, strategic planning implementation in schools is affected by factors such as lack of preparation for head teachers and instructors, shortage of strategic planning abilities, lack of resources due to heavy teaching workloads, inadequate funding (Cheruiyot, 2014).

\section{STATEMENT OF THE PROBLEM}

The Government of Kenya has insisted on the use strategic planning in schools. However, a number of factors either facilitated or hindered the study schools' engagement in strategic planning: knowledge and awareness of strategic planning, leadership styles, financial resources, training and professional support. This raises questions as to how this process affects or contributes to the performance of head teachers in primary schools (Wanjala, 2014). A knowledge gap exists regarding the perceptions of headteachers towards the implementation of strategic planning processes and their performance in public primary schools.

\section{PURPOSE OF THE STUDY}

The purpose of this study was to determine the relationship between the perceived effects of the implementation of strategic planning process and head teachers' performance in public day primary schools in Kericho County of Kenya.

\section{HYPOTHESES OF THE STUDY}

The following hypotheses were tested at 0.05 alpha level: -

$\mathbf{H}_{\mathrm{O} 1}$ : There is no statistically significant relationship between the perceived effects of the implementation of strategic planning process and head teachers' performance in public day primary schools in Kericho County of Kenya

\section{LITERATURE REVIEW}

\section{PERFORMANCE MANAGEMENT}

Rummler \& Brache (2012) defined performance management as the process by which employees are encouraged to work as effectively and efficiently as possible to meet the organization's needs. Macharia (2013) found that much attention has been given to performance management. As a result, the assumption led to the risk of finding that public service in many countries in Africa (Karyeija, 2012). These include human resource factors, which are associated with the lack of staff in the number and key competencies. On the contrary, ethical erosion and accountability gradually forced the public sector to make good public service to the people. Challenges have yielded minimal results. Performance improvement strategies have the potential to change the way public services are delivered.

\section{PERFORMANCE MANAGEMENT PROCESS}

According to Page (2015), an effective performance management system should encompass many personnel management activities. These would include: the recruitment and retention of staff; the selection and appointment of staff; those clauses of collective and individual employment contracts which relate to the performance management of staff; the statutory requirements for registration; the appraisal and assessment of staff; the professional development and succession planning; remuneration management; and the discipline and dismissal of staff.

\section{IMPLEMENTATION OF STRATEGIC PLANNING PROCESS AND HEAD TEACHERS' PERFORMANCE}

Chukwumah and Ezeugbor (2015) investigated the extent of problems of strategic plans implementation for secondary schools' improvement in Anambra State, Nigeria for quality education provision. The study 
established that strategic plan implementation is still within average level in secondary schools. The study however, did not examine how this level of implementation affected the performance of headteachers.

Owino and Oloko (2015) looked at the factors affecting strategic plans implementation practice in public secondary schools in Kenya. The study established that when school managers are effectively trained on strategic planning they will facilitate a proper strategic plans implementation practice in public secondary schools in Kenya since they are normally given the duties to monitor the whole exercise by the school heads. The study however, did not examine how implementation of strategic planning influenced their head teachers' performance.

\section{CURRENT STATUS OF PERFORMANCE}

According to Farrell (2013), today's organizations have four main performance assessment applications. These are single comparisons, system maintenance and documentation. Between Individuals It refers to individual performance comparisons in individuals who focus on identifying and developing individual strengths and weaknesses. System maintenance is the use of Performance Evaluation as a source for linking business processes and strategies with the performance of employees and goals they have achieved and are in progress. Connecting the performance appraisal to the company's business goals has been seen as an innovative way to streamline employee actions with company priorities. The key is to develop a comprehensive performance management system that includes goal setting, development, compensation, performance feedback, and goaloriented performance evaluation" (Lawler \& Ashman, 2012).

\section{ENVIRONMENTAL ANALYSIS}

Chukwumah and Ezeugbor (2015) pointed out that managers do not sufficiently understand the strategic planning process. This was demonstrated by the fact that there was no record of environmental analyzes in all the schools studied. Therefore, the researcher concludes that both urban and rural schools find it almost as difficult to implement their strategic plans, especially with limited knowledge and in the absence of environmental analyzes.
Okwako (2013) investigated whether school managers performed environmental analysis during strategic planning in public schools in Rarieda district, Kenya. The study found that the extent of stakeholder involvement and environmental analysis during strategic planning is only moderate. However, the study did not establish the perceived effects of the implementation of strategic planning process and head teachers' performance in public day primary schools in Kericho County of Kenya.

\section{FORMULATION OF STRATEGIES}

Wanjiku (2014) investigated strategic management at Parklands Primary School, Kenya. The study found that failure to formulate an inclusive strategic plan where every member of staff is involved leads to the failure of its implementation and achievement, Therefore managers should ensure that all the employees are involved since they are the implementers of the plan on the ground. Best practices of management can be used by managers to describe relationships between variables and used in proposing what to be done to achieve organizations objective.

Njiru (2014) investigated strategy formulation process in public secondary schools in Embu County, Kenya. The sample was made up of 147 secondary schools in Embu County. The study also found that most of the participants in the strategy formulation process face very many challenges which mainly included lack finances and lack experts and skills. This means that the strategy formulation process was not properly done due to these challenges.

\section{MONITORING AND EVALUATION}

Dziyaba (2016) in Ghana observed that most organizations that had successfully implemented strategic plans had taken monitoring and evaluation seriously. The monitoring plan or M\&E is the highlight of this study. However, Dziyaba's study did not look at how this aspect of monitoring and evaluation affected the performance of school managers.

Onkundi (2011) studied the effectiveness of strategic planning in public primary schools in Suneka Division, Kisii County, Kenya. Educational stakeholders do not understand the framework compositions of strategic plans, not all schools formulate strategic plans follow all the 
strategic planning process, and those schools that had strategic plans appeared to have ignored the monitoring and evaluation component.

\section{HEADTEACHERS PERFORMANCE}

Apebende and Ushie (2018) explain that the Head Teacher is the sole administrator of the school. Their duty according to Nwaka (2009) is to plan and equip the teachers with facilities, materials and equipment to make teaching and learning meaningful. Head Teacher as a leader has to plan, direct and control the resources under his care to enable him / her to achieve such goals or aims.

According to Reche Bundi, Riungu and Mbugua (2012) poor performance of headteachers is characterised by poor performance in primary national examination; inadequate learning resources, inadequate monitoring by head teachers, understaffing, high teacher turnover rate, inadequate prior preparation, lack of motivation for teachers, large workload, and high levels of teacher absenteeism.

\section{THEORETICAL FRAMEWORK}

This study was supported by the Henry Mintzberg Theory and the Expectancy Theory by Victor Vroom

\section{THE MANAGEMENT THEORY OF HENRY MINTZBERG}

The study was supported by the Management Theory of Henry Mintzberg Mintzberg in 1991. Mintzberg believes that skills are learned through experience and cannot simply be taught in the classroom. Mintzberg proposes that managerial work can best be described, discussed, and taught by focusing on the activities in which managers engage. The theory is relevant to this study in that it stresses the fact that head teachers need to acquire requisite skills for strategic planning. The theory upholds the view that where head teachers fail to adhere to the process of strategic planning then it may result into failure of the school.

\section{EXPECTANCY THEORY}

This study is supported by the Expectancy Theory, which was postulated by Victor Vroom in 1964. This theory is based on the idea that individuals in the organisation change their actions based on expected fulfillment with cherished goals that they set. This theory underlies the principle of performance management, since success is assumed to be determined by assumptions about future events. In the context of this study, implementation of strategic planning process helps head teachers' enhance their performance in primary schools.

\section{RESEARCH METHODOLOGY}

The study used convergent mixed methods (quantitative and qualitative). Mixed methods approach is based on the pragmatism philosophical worldview. This study used the Ex facto-post facto research design.

This study was conducted Ainamoi, Belgut, Soin/Sigowet, Londiani, Kipkelion and Bureti Sub-counties of Kericho County. The target populations composed of 524 head teachers of public primary schools TSC sub County directors in Kericho County.

The sample size of 227 Head teachers was determined by using the Solvin formula as recommended by Altares (2003). Sample of headteachers were selected using Simple random sampling technique. Purposive sampling was used to sample the six TSC sub County directors in Kericho County of Kenya.

The questionnaire was used to collect information from head teachers while an interview schedule captured information from the Sub County Director of Education. Prior to use the instruments were subjected to validity check and reliability tests and were adapted after yielding a score of 0.741 , above the recommended 0.7 .

The researcher obtained requisite authorisation and permit prior to data collection. Such included an introductory letter from University of Kabianga, and the National Commission of Science, Technology and Innovation (NACOSTI) permit, and authorisation from County Commissioners and the County Directors of Education of Kericho County. The researcher personally administered data collection.

Before the actual data analysis, the gathered data was validated, edited and then coded, and entered into appropriate category in a computer worksheet using SPSS (Version 25) for both qualitative and quantitative analysis. Quantitative data was analysed for descriptive statistics (frequencies, means and percentages) and inferential statistics (Pearson Correlation and Regression analysis). The results were presented using tables and charts. On the other hand, qualitative data was analysed using textually analysis, and presented in narratives. 


\section{RESULTS AND DISCUSSIONS}

\section{RESPONDENTS RESPONSE RATE}

The researcher distributed 233 questionnaires to teachers and headteachers in public primary schools in Kericho County, and interviewed six (6) TSC Sub County Directors. Out of the 233 questionnaires administered, the researcher was able to obtain a $90.7 \%$ response rate and $100 \%$ response rate from Sub County Directors. The percentage was considered ideal as it surpasses recommended percentage responses by scholars such as Dommeyer, Baum and Hanna (2002) for paper surveys.

\section{DEMOGRAPHIC CHARACTERISTICS}

Majority of the headteachers $(73.6 \%)$ were aged 41 to 45 years. The result also shows that $59.2 \%$ of the teachers participating in the study were male, while $40.8 \%$ were female. Majority of the respondents $(74.5 \%)$ had an employment experience of over 20 years. The data indicate that majority of the respondents had a Diploma in Education. Majority of the head teachers (over $60 \%$ ) had been in their stations for the period that the researcher was interested in and therefore capable of giving the required information.

\section{DESCRIPTIVE STATISTICS FOR THE IMPLEMENTATION OF STRATEGIC PLANNING PROCESS}

The headteachers were asked to indicate their perceptions towards the relationship between the implementations of strategic planning process and their performance as headteachers. A Likert scale containing 5 measures as follows: (1) strongly disagree. (2) Disagree, (3) Somehow Agree, (4) Agree, and (5) Strongly Agree was used. The results in Table 4 reveal that the creating or affirming the vision and mission (guiding principles) ( $\overline{\mathbf{X}}=3.71$ ) and undertaking an analysis of the environment in which it operates (analysis of environment) ( $\bar{X}=3.65$ were perceived by the headteachers to somehow influence their performance. The findings agree with study by Mulford (2003) who found out that, school leaders who are honest, communicative, and demanding and reasonable in their expectations with a clear vision for the school receive requisite support from teachers. The results from the Sub County Directors revealed that the strategic plan implementation is still within average level in the primary schools. One Sub County Director is quoted saying. "My observation is that even though the headteachers' are trying their best in implementing the strategic plans, most of them have not mastered the strategic planning process well."

The results provided in Table 4 reveal that strategic goals, objectives, strategies and key results based on the information gathered and assessed ( $\bar{X}=3.57$ ) and developing action plans based on strategic objectives (where do we want to go?) ( $\bar{X}=3.57$ ) were perceived by the headteachers to somehow influence their performance. The findings agree with those in a study by Day (2011) where it was highlighted that headteachers who were efficient in the preparation of strategic goals, objectives, strategies and associated key results registered higher performance outcomes. The results from the Sub County Directors revealed that the strategic plan implementation is still within average level in the primary schools collected through interview schedules revealed that the headteachers still experienced challenges in the preparation of work plans, and in some cases action plans were found with many mistakes. One Sub County stated. "The headteachers can do a good job with strategic plans, but not without supervision, as there are many glaring mistakes spotted in their action plans".

The results provided in Table 4 reveal that the headteachers somehow agreed that the strategic planning process had some effect on their performance. Specifically, maintaining cumulative records of teaching and learning for decision making ( $\overline{\mathbf{X}}=3.39)$ and monitoring and evaluating of the strategic planning process ( $\overline{\mathbf{X}}$ $=3.55$ ) were perceived by the headteachers to somehow influence their performance. The results resonate with those in a study by Ahmed, Malik and Ahmed (2019) whereby it was established headteachers' task of verifying the proper maintenance of school records, like cumulative records, examination registers progress records contributed positively to their performance. The results are also in agreement with those in a study by Miller (2017), which revealed that monitoring and evaluation gives headteachers a basis for both questioning and testing assumptions and helps them in planning. 
Table 1: Descriptive Statistics for Strategic Planning Process $\mathbf{N}=201$

\begin{tabular}{lll}
\hline & Mean & Std. Deviation \\
\hline Creating or affirming the vision and mission & 3.71 & .85684 \\
Analysis of operational environment & 3.65 & .87069 \\
Preparing strategic goals, objectives, strategies and key results & 3.57 & .96191 \\
based on the information gathered and assessed. & & \\
Developing action plans based on strategic objectives & 3.57 & .89779 \\
Maintaining cumulative T \& L records for decision making & 3.39 & 1.01968 \\
M \& E for Strategic planning process & 3.55 & .88261 \\
Valid N (listwise) & & \\
\hline
\end{tabular}

ASSOCIATION BETWEEN STUDY VARIABLES The results provided in Table 5 reveal that there was a positive correlation between implementation of strategic planning process and head teachers' performance in public day schools in Kericho County at $(r=135 ; p=0.056)$. The $p$ value was slightly above the test significant level at 0.05 , thus implying that the association between strategic planning process and head teachers' performance was statistically insignificant.

The results from the sub County directors however, revealed that all the head teachers were not efficiently using strategic plans. One Sub County Director is quoted saying: "Even though the headteachers are trying their best to implement strategic plans, the process of implementation is done haphazardly in many schools. This even affects their usefulness in supporting the head teachers' work." The results from the sub County directors resonate with those in a study by Onkundi (2011) who found that primary schools were ineffective in strategic planning.

Table 2: Correlation between Study Variables

\begin{tabular}{llll}
\hline & & $\begin{array}{l}\text { Strategic Planning } \\
\text { Process }\end{array}$ & $\begin{array}{l}\text { Headteachers' } \\
\text { Performance }\end{array}$ \\
\hline Strategic Planning & Pearson Correlation & 1 & .135 \\
Process & Sig. (2-tailed) & 201 & .056 \\
& $\mathrm{~N}$ & 201 \\
Headteachers' & Pearson Correlation & .135 & 1 \\
Performance & Sig. (2-tailed) & .056 & 201 \\
& $\mathrm{~N}$ & 201 & 201 \\
\hline
\end{tabular}

\section{HEADTEACHERS' PERFORMANCE}

The results in Table 6 show that the performance dimension for the maintenance of teaching standards in curriculum implementation and delivery recorded a mean score of (3.68). Performance dimension for monitoring of the conducts and performance of teachers recorded a mean score of (3.65); ensuring actual teaching and learning takes place (3.52); Supervise and appraise teachings using prescribed tool (3.58); and ensuring prudent management of human resources, materials and financial resources (3.63). All these indicated that the performance of headteachers was fair. The results agree with a study by Awiti and Raburu (2013) and Ithibutu (2017), where it was found that head teachers performance was fair. 


\section{Table 3: Descriptive Statistics for Headteachers' Performance}

\begin{tabular}{lll}
\hline & Mean & Std. Deviation \\
\hline Maintenance of teaching standards in curriculum implementation & 3.68 & .69865 \\
and delivery & 3.65 & .73458 \\
Monitor the conducts and performance of teachers & 3.52 & .78150 \\
Ensure actual teaching and learning takes place & 3.58 & .73789 \\
Supervise and appraise teachings using prescribed tool & 3.63 & .74416 \\
Ensure prudent management of human resources, materials and & & \\
financial resources & & \\
Valid N (listwise) &
\end{tabular}

\section{REGRESSIONS}

The variables under regression analysis comprised the relationship between implementation of strategic planning process (Independent variable) and Headteachers' Performance in primary day schools (dependent variable).

\section{MODEL SUMMARY}

The $R$ Square value $(0.40)$ in the Model Summary table shows the amount of variance in the dependent variable that can be explained by the independent variables. The independent variables listed below Table 7 accounted for 4 percent of the variability in headteachers' performance. The R-value (.200) is the linear correlation coefficients between all the entered independent variables and Headteachers' Performance in primary day schools.

Table 4: Model Summary

\begin{tabular}{lllll}
\hline Model & R & R Square & Adjusted R Square & Std. Error of the Estimate \\
\hline 1 & $.200 a$ & .040 & .035 & .56469 \\
\hline
\end{tabular}

a. Predictors: (Constant) Strategic Planning Process

\section{ANALYSIS OF VARIANCES (ANOVA)}

In the study, the predictors are significant when Sig. ( $p$ value) $p<0.05$. The findings in Table 8 show that $p$ value was 0.005 . As $p<0.05$ our predictors are significantly better than would be expected by chance. The regression line predicted by implementation of performance management processes explains a significant amount of the variance in head teacher performance in primary day schools. This is reported as follows: $F(1,199)=8.249 ; p<0.005$, and therefore can conclude that the regression is statistically significant.

Table 5: Analysis of Variances (ANOVA)

\begin{tabular}{llllll}
\hline Model & Sum of Squares & df & Mean Square & F & Sig. \\
\hline $1 \quad$ Regression & 2.630 & 1 & 2.630 & 8.249 & $.005^{b}$ \\
Residual & 63.456 & 199 & .319 & & \\
$\quad$ Total & 66.086 & 200 & & & \\
\hline
\end{tabular}

a. Dependent Variable: Headteachers' Performance

b. Predictors: (Constant) Strategic Planning Process

\section{BETA COEFFICIENTS}

The following regression model was used $\mathrm{Y}=\beta_{0}+\beta_{1} \mathrm{SPP}+\varepsilon$ $3.288+0.091+0-174$

From the findings, it emerges that the beta value for strategic planning process $($ Beta $=0.136 ; p=$
0.004 ), and performance appraisal process (Beta $=0.132 ; p=0.005)$. The findings thus show that strategic planning process was a positive predictor to headteachers' performance. 
Table 6: Beta Coefficients

\begin{tabular}{llllll}
\hline Model & \multicolumn{2}{l}{ Unstandardized Coefficients } & $\mathbf{t}$ & Sig. \\
& & B & Std. Error & & \\
\hline 1 & (Constant) & 3.144 & .168 & 18.711 & .000 \\
& Strategic Planning Process & .132 & .046 & 2.872 & .005 \\
\hline
\end{tabular}

a. Dependent Variable: Headteachers' Performance

\section{TEST OF HYPOTHESIS}

Using coefficients outputs for the independent and dependent variables in Table 9, the study hypothesis was tested. The decision rule was to reject the null hypotheses if $p$ values computed from the regression outputs per variable under measure were less than the conventional value of 0.05. The first hypothesis stated that " $\mathrm{H}_{\mathrm{O} 1}$ : There is no statistically significant relationship between the perceived effects of the implementation of strategic planning process and head teachers' performance in public day primary schools in Kericho County of Kenya." Results in Table 9 show outputs as (Beta $=0.132 ; p=0.005)$. Since the $p$ value associated with implementation of strategic planning process was 0.005 , a value less than the test significance level of 0.05 , the null hypothesis is rejected. This output suggests that implementation of strategic planning process has a positive statistically significant relationship with head teachers' performance primary day schools in Kericho County.

\section{CONCLUSIONS}

The study concludes that implementation of strategic planning process did not have a statistically significant relationship with head teachers' performance in primary day schools in Kericho County. Moreover, it is important to note that in some of the schools in the County, the act of creating or affirming the vision and mission (guiding principles); and undertaking an analysis of the environment in which it operates (analysis of environment) did not significantly influence headteachers' performance. In some of the schools preparation of strategic goals, objectives, strategies and key results based on the information gathered, development of action plans based on strategic objectives, maintaining cumulative records of teaching and learning for decision making did not significantly influence headteachers' performance. Monitoring and evaluating plan are developed to enable their school evaluate progress and update plans on regular basis failed to contribute favourably to head teachers' performance in some of the schools in the County. Therefore it is safe to conclude that strategic planning process as embraced in the schools was not effective in influencing head teachers' performance in some of the schools in the County.

\section{RECOMMENDATIONS}

Following the findings and conclusions the study recommended the following.

i. The Ministry of Education should consider strengthening the monitoring systems so as to be proactive in enhancing the success of strategic planning processes in primary schools. This will help check on the efficacy of processes such as creating or affirming the vision and mission (guiding principles); and undertaking an analysis of the environment in which it operates.

ii. The school management should consider mobilising resources for organizing update training for headteachers on strategic planning process, with specific reference to aspects such as strategy formulation (preparation of strategic goals, objectives, and strategies).

iii. The school management should consider taking seriously and acting promptly on the feedback from the BOM and County Director with regard to the implementation of the strategic plans. 
SUGGESTIONS FOR FURTHER STUDIES

i. Future research should be done to determine headteachers' competencies in strategic management and strategy implementation success in public primary schools.

\section{REFERENCES}

Ahmed, S. Malik, S. and Ahmed, H., 2019. Role of high-school teachers in academic decision-making practices: A Comparative Study of Two Provinces of Pakistan. Bulletin of Education and Research April 2019, Vol. 41, No. 1 pp. 67-84.

Alubbe, F., 2015. Factors influencing the Implementation of Teacher's Performance Appraisal System; Case of Public Secondary Schools in Westland's County.

Altares, P. S., 2003. Elementary Statistics: A Modern Approach 2003 Ed. Legaspi City: Rex Book Store, Inc.

Barney, J., 2007. Gaining and Sustaining Competitive Advantage. New Jersey: Pearson Hall.

Berg, J., 2015. Project Planning and Management for Ecological Restoration. Restoration Ecology, 23 (3) 328-329.

Chukwumah, F., and Ezeugbor, C., 2015. Problems of implementation of strategic plans for secondary schools' improvement in Anambra State

Farrell, M., 2013. Lifecycle of library leadership. Journal of Library Administration, 56 (6) 225-264.

Ithibutu, J., 2017. Influence of Headteachers' Financial Practices on Management of Physical Resources in Public Primary Schools in Igembe Central Sub-County, Kenya. University of Nairobi

Johnson, G., Scholes, K., Whittington, R., and Johnson, G. (2011). Exploring strategy. Harlow: Financial Times Prentice Hall.
Jonyo, D. and Jonyo, B., 2017. Performance management in Kenyan public schools: implications and challenges. European Journal of Educational Sciences, EJES, 4(3), 19-35.

Karyeija, G. K., 2012. Public sector reforms in Africa: What lessons have we learnt. In Forum for Development Studies, 39 (1), 105-124.

Lawler, J., and Ashman, I., 2012. Theorizing leadership authenticity: A Sartrean perspective. Leadership, 8 (4), 327-344.

Macharia, J. M., 2013. Strategy Implementation at Chase Bank, Kenya. Nairobi: School of Business, University of Nairobi, Kenya.

Manduku, J. G., 2012. Factors influencing adoption of PA systems. A conceptual examination of perfomance contracting among teahcing staff of NOB of Kentatta University. Kenyatta University.

Mbugua, F. and Rarieya, J., 2014, Collaborative Strategic Planning: Myth or Reality?, Educational Management Administration and Leadership 42(1): 99-111.

Miller, D., 2017. Importance of School Monitoring And Evaluation Systems. Available at http://leansystemssociety.org/importance -of-school-monitoring-and-evaluationsystems/

Mulford, B., 2003. School Leaders: Challenging Roles and Impact on Teacher and School Effectiveness. University of Tasmania

Okwako, D., 2013. Strategic Planning And Performance Of Public Secondary Schools In Rarieda District, Kenya. University of Nairobi.

Onkundi, P., 2011. Effectiveness of Strategic Planning in Primary Schools: A Case of Suneka Division, Kisii County, Kenya. Kenyatta University

Page, D., 2015. Understanding performance management in schools: a dialectical 
Reche, G. Bundi, T. Riungu, J. and Mbugua, Z., 2012. Factors contributing to poor performance in kenya certificate of primary education in public day primary Schools in Mwimbi Division, Maara District, Kenya. International Journal of Humanities and Social Science, 2 (5), $127-134$

Rummler, G. A., and Brache, A. P., 2012. Improving performance: How to manage the white space on the organization chart. New Jersey: John Wiley and Sons.

Thompson, A. J., Strickland, A., and Gamble, J., 2010. Crafting and executing strategy: the quest for competitive advantage : concepts and cases. New
Wangari, H., 2011. Strategy implementation challenges faced by national hospital insurance fund in Kenya. Unpublished MBA Project. University of Nairobi.

Wanjala, C. and Rarieya, A., 2014. Strategic Planning in Schools in Kenya: Possibilities and Challenges. International Studies in Educational Admnistration. 42.

Wanjiku, M. E., 2014. Availability and utilization of educational resources in influencing student's performance in secondary schools in Mbeere South, Embu County, Kenya. MED Thesis Kenyatta University.

Yabs, J., 2007. Strategic M anagem ent Practices in $\mathrm{K}$ enya Applications and Cases. Lelax Global 